\section{Soviets put on impressive show}

\section{Moscow \& Washington}

LAST week's visit of US scientists and arms negotiators to the Soviet Semipalatinsk test site to witness an underground nuclear test was a success, according to US officials. Speaking in Moscow, C. Paul Robinson, chief US arms negotiator, said that talks would now go ahead in Geneva to try to ratify two nuclear test treaties before US President Ronald Reagan leaves office.

The two treaties are the Threshold Test Ban Treaty of 1974 and the Peaceful Nuclear Explosions Treaty of 1976. Both would limit underground tests to 150 kilotons but neither has been ratified, chiefly because of US fears that it would not be possibe to detect violations.

The Semipalatinsk test follows by a few weeks an almost identical test at the US Nevada site (see Nature 334, 641; 1988), where Soviet officials monitored the explosion of a US nuclear bomb. Of the two tests, the Soviets provided the closer view. Trailers full of monitoring equipment were set up two and a half miles from the 1,800-foot-deep borehole containing the nuclear bomb, in contrast to the US test where observers were kept thirty miles away. Before the Soviet bomb was triggered, the monitoring team was told to "bend their knees like skiers" accordin to Robinson. Even so, the force of the shockwave, which blew the ground into an eight-foot-high bubble above the borehole, came as a jolt.

Data from the two tests are intended to resolve differences between the Soviet Union and United States over what kind of procedures will make it possible to monitor nuclear tests accurately. The US side has favoured the highly intrusive CORRTEX technique that requires a cable to be placed in a hole alongside the bomb. The Soviets have aruged that longdistance seismic monitoring is adequate.

First results from the Nevada test caused some embarrassment to the US administration when it was claimed that CORRTEX showed the explosion to have violated the 150 -kiloton unratified treaty limit. Traditional seismic methods apparently gave lower values closer to the expected yield. The results support the view of many scientists that all methods have some uncertainties and that seismic methods are adequate.

The United States and Soviet Union will now try to decide on the mix of CORRTEX and seismic techniques that will satisfy both sides that the other is not cheating. The Soviet Union has been opposed to the use of CORRTEX but now appears resigned to its inclusion.

Mary Manning \& Alun Anderson

\title{
Harvard starts own marketing venture at "arms length"
}

\section{Boston}

Harvard University plans to establish a limited partnership with a private investment consortium so as to be able to profit directly from the fruits of its own faculty's research.

The university will not be the first in the United States to undertake such an initiative, but its decision to play a role in the commercialization of faculty research marks a reversal of its well publicized policy of not taking a direct interest in commercial ventures springing from faculty research.

Almost exactly eight years ago, after much debate, Harvard officials rejected a similar plan to form a genetic engineering company with biochemistry professor Mark Ptashne. In a widely distributed report in 1980, Harvard president Derek C. Bok warned that such entrepreneurial ventures on the part of the university could compromise its objectives by "introducing into the very heart of the academic enterprise a new and powerful motive the search for commercial utility and financial gain." Despite such warnings, the university's new plan seeks ultimately to identify research with lucrative commercial possibilities and establish small "spin-off" companies. The new arrangement, which will focus initially upon bio- medical research at the Harvard Medical School and affiliated hospitals, involves an intricate scheme to keep the university at "arm's length" from financial decisions.

Specifically, the university plans to form a subsidiary, called Ion Inc., which will join a limited partnership of six to eight outside, institutional investors. This group will attempt to raise an initial $\$ 30$ million that will, in turn, be managed by another investment concern headed by Andre L. Lamotte, a former drug company executive recruited by Harvard Medical School for the job.

In exchange for providing start-up capital, the university will receive ten percent of the profits from any new companies formed after the initial investment in them has been repaid. If the companies are sold, the university will be entitled to a tenth of the capital gains arising. The money raised by Harvard through the venture will be used to augment university support for basic research.

Officals at the university stress the goals of bringing products to market more rapidly and of "fostering a class of inventions that traditionally fall between the cracks". These are often too small and unformed to interest industry but too applied for government and foundation support.

Seth Shulman

\section{Fetal tissue panel labours to beat a presidential ban}

\section{Washington}

THE Human Fetal Tissue Transplantation Research Advisory Panel, meeting for two days last week at the US National Institutes of Health (NIH), failed to conclude its work on a report on the scientific, legal and ethical issues involved in such research. But the panel did endorse the basic premise that "the use of postmortem fetal tissue for purposes of research and therapy that has been obtained from legally performed abortions is acceptable".

The panel was convened at the request of Health and Human Services Assistant Secretary Robert Windom, who ordered a moratorium on federal funds for fetal tissue research pending the outcome of the panel's deliberations. Arlin Adams, a retired federal judge, chaired the panel, with Kenneth Ryan of Harvard Medical School and LeRoy Walters of the Center for Bioethics at Georgetown University as cochairmen.

The most troublesome problem seems to be that of distinguishing between the use of fetal tissue and the manner in which it is obtained. Inevitably, the panel was forced to go over some well-trodden ground on the ethical issues concerning abortion. But there was a consensus that new ground had been covered on the ethical questions raised by fetal tissue research, including what constitutes "informed consent" for its use - and who should have the authority to give it.

After two and a half days of deliberations, the panel decided that another meeting is needed to provide answers to the questions that Windom posed in a letter last March. The panel must conclude its work by the end of November, so that its views can be considered at a meeting of the NIH director's advisory committee in December

Hanging over the session was the threat of a pre-emptive executive order by President Reagan banning all fetal tissue research (see Nature 335, 197; 1988). The White House has said that the order is still being considered, but administration officials have made it clear that they do not feel bound to wait for the NIH panel to produce its report.

Joseph Palca 